\title{
The Implementation Of Neighborhood Walk Strategy To Improve Students' Writing Descriptive Text At Class V Of Sd Inpres Btn Ikip II, Rappocini Makassar.
}

\author{
Syamsiah $\mathrm{D}^{1}$, Johara Nonci ${ }^{2}$, Syamsuryani Eka Putri $\mathrm{A}^{3}$ \\ \{ syamsiahdjaga@gmail.com ${ }^{1}$,joharanonci@unm.ac.id ${ }^{2}$,syamsuryani@unm.ac.id ${ }^{3}$ \} \\ 1,2,3 PGSD FIP UNM, Indonesia
}

\begin{abstract}
The problem in this study is there are still many elementary students who have not been able to express ideas in writing. This study aims to describe the ability to write student descriptions through the Neighborhood Walk Strategy. Research data in the form of teacher teaching activities and student learning through observation format then the ability to writing descriptions through written tests. The implementation of the Neighborhood Walk strategy is carried out in two cycles, which consist of four stages, namely planning, implementing actions, observing, and reflecting. The results showed that the application of the Neighborhood Walk strategy to teacher teaching activities and student learning activities in Indonesian language learning after improvements occurred in each cycle were in good qualifications and the ability to write descriptions in the Good category. The conclusion of this research is that the application of the Neighborhood Walk Strategy can improve the ability to write description of students at Elementary School.
\end{abstract}

Keywords: Neighborhood walk strategy, write description, elementary students

\section{INTRODUCTION}

Indonesian language learning basically aims to improve the ability of students to use Indonesian, both verbally and in writing. In essence, learning Indonesian is learning to communicate. Indonesian learning is directed to improve students' ability to communicate in Indonesian both verbally and in writing (Puskur, 2003).

The essence of Indonesian language learning in elementary schools is more emphasized on aspects of mastery of language skills. Suparno (2001: 1) states that Indonesian language learning is directed to form communicative competence, namely the ability to use Indonesian as a communication tool, both aspects of understanding, aspects of use, and aspects of appreciation. The skills developed in language learning are receptive language skills (listening and reading) and productive language skills (speaking and writing skills). Skills are taught in an integrated way between one skill and other language skills. The integrated learning of Indonesian language is implicit in the 1994 curriculum in Indonesian subjects.

The four skills mentioned above, have been taught since class I. The Writing skills as one of the language skills is a skill that elementary school students need to have in order to be able to communicate in writing. In the 1994 curriculum, it was stated that students should be able to express ideas, opinions, experiences, and messages verbally or in writing (Depdikbud, 
1994: 4). Writing as one of the language skills, is a product of ongoing learning that needs to be done continuously since in elementary school (elementary school). This can be based on the thought that the ability to write in elementary school is the basis for learning to write.

In the above definition, then in written communication there are at least four elements involved, namely the writer as the messenger, the message or content of the writing, the channel or media in the form of writing, and the reader as the recipient of the message. Writing can be defined as a delivery of messages (communication) with written language as a tool or medium (Suparno, 2000: 1-3). The expected learning objectives in teaching writing are that students are able to express ideas, opinions, knowledge in writing, and have the ability to write (Depdikbud, 1994/1995: 9). With these skills, students will develop their creativity and can also use them as valuable tools in various ways to learn.

The reality on the ground shows that there are still many elementary students who have not been able and are not yet perfect in expressing ideas in writing. This needs to be realized, because writing is a very complex skill. There are several factors that are interrelated and influence and become a requirement for the success of writing activities, namely (1) processing ideas, (2) structuring sentences, (3) developing paragraphs, and (4) developing essays in certain types of discourse Widodo (Prasetio, 2003). In addition, writing skills will become a competency possessed by someone if practiced repeatedly (Suparno and Yunus, 2002: 1-5).

The above causes are not due to student limitations, but because of the inaccurate approach used. The teacher does not direct students to be able to learn how to write well, but students are invited to do their best with difficult and unclear tasks (Tompkins: 1991: 227). According to Kustino (1996: 42), the teacher's habit of carrying out conventional and elementary teaching and learning activities, makes the teacher slow to think of more real learning alternatives. For example, by taking children outside the room for practical learning purposes. Another difficulty that arises in writing is how to start writing. As revealed by Shafi'ie. (1988: 47) that the difficulty to start writing usually arises because of the difficulty in putting together the first sentence.

The conditions illustrated above indicate that learning to write descriptions in elementary schools is still ineffective. Less effective learning in research schools has an impact on the lack of students' ability to make writing that meets good criteria. This is reinforced by the results of observations and questions and answers conducted by researchers in February 2014 of the fifth grade teachers of SD Inpres BTN IKIP II, Rappocini District, Makassar City, revealed that the learning outcomes of Indonesian students in class $\mathrm{V}$ are still low, where the value of Indonesian Language in semester I from 23 students, 12 students passed, while 11 students did not pass. This means that only $52 \%$ of students graduate individually with a grade of 75 and meet the Minimum Mastery Criteria (KKM), which is $85 \%$ classically.

The above situation, allegedly because the teacher is in the planning stage until the evaluation of learning does not connect the object of writing with the students' real life (contextual). In learning to write a description based on a contextual approach, the teacher can invite students to directly interact with the written object. One of the strategies that can be used in learning to write contextual descriptions is the Neighborhood walk strategy.

Neighborhood walk learning strategy is a learning strategy that in learning activities utilizes and introduces the surrounding environment as a media and learning resource that is direct, contextual, and can be fun. The application of the Neighborhood walk strategy in learning is based on learning with an environmental approach. Frederieks (Ramli, 1999: 3031) states that "learning by utilizing the environment is based on the idea where children must 
first be able to relate to their immediate environment, then systematically goes to a wider scope.

In learning to write descriptions, the application of the Neighborhood walk strategy is done by directly inviting students to walk around the environment. While walking students will observe and try to identify the object being observed. Nasution (Kustiono 1996: 44) states that one of the lessons by utilizing the environment as a learning resource is "bringing children into the environment for teaching purposes (through various methods such as: field trips, service projects, school camping, surveys, and interviews). In addition the Neighborhood walk strategy can also be integrated with learning discovery in applying the principle of learning community (Suyanto, 2002).

One form of writing taught in elementary school is writing descriptions. The word description comes from the Latin word "describery" which means to describe or give something. From the term description is a form of writing that describes something in accordance with the actual situation, so that readers can image (see, hear, smell, and feel) what is described in accordance with the image of the author (Suparno, 2000: 4-5). Writing a description is a writing activity that contains a painting (depiction) in accordance with the actual situation. While writing descriptions is to paint pictures using words. Students need to be observant observers by paying attention to sensory imagery. Ellis et al (1989: 175) state that describing an object trains novice writers to observe known material, gather various details, organize, and select ideas. Thus it can be concluded that the description is the result of observation through the five senses conveyed in words.

Although it is realized that mastery of written language is absolutely necessary in modern life, in reality teaching of reading and writing skills is still lacking in attention. Writing teaching as one aspect of teaching Indonesian is less seriously handled as a result, the students' Indonesian language abilities are inadequate. Several studies conducted on learning to write descriptions include the following. The first research conducted by Lemien Leiwakabessy Wattimury (2000), namely Learning to Write Descriptions with Process Approaches for Grade V Elementary Students. The results show an increase in students' ability to write descriptions in the stages of Pre-writing, editing, refining, editing, and publishing. Second. Syamsiah (2005) with the title research Effect of Form of Feedback and Learning Motivation on Acquiring Learning to Write Descriptions in Teaching Indonesian Grade V SD Inpres Tamalanrea II Makassar City, concludes that the writing ability of elementary school students is still low, both after being given written feedback and meeting feedback, so it still needs to be followed up with learning strategies / approaches that can improve students' abilities in writing.

\section{RESEARCH METHODS}

This study uses a qualitative approach to the type of research used is classroom action research. This research is planned to have 3 cycles and each cycle has 2 meetings and each meeting involves planning, implementing, observing / evaluating, and reflecting activities.

The subjects of this study were teachers and class V students who were active and registered in the even semester which amounted to 38 students, 9 of whom were male while 29 were female. The Research Focus is (1) Implementation of the Neighborhood Walk strategy to improve teacher teaching activities and student learning activities, (2) Learning outcomes of writing descriptions for fifth grade students of SD Inpres BTN IKIP II, Rappocini District, 
Makassar City after the Neighborhood Strategy is applied. The PTK research design used was developed by Kemmis and MC Taggart (1992: 11) as follows:

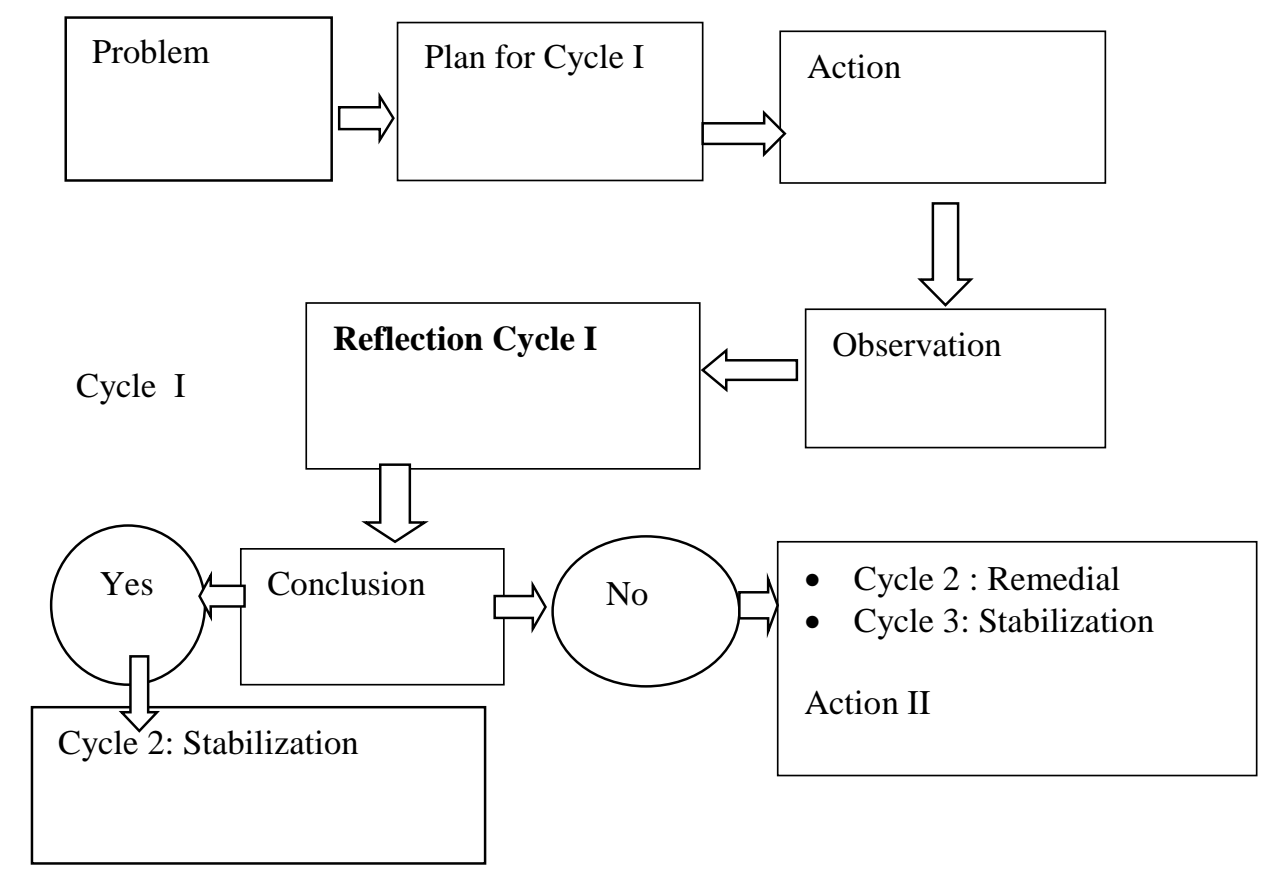

Figure 3.1. The Action Research Flow is adapted from the Kemmis and Mc Taggart Models

The data collection techniques used are (1). Observation: conducted to observe the suitability between the implementation of the actions and plans that have been prepared and to know the extent to which the implementation of the actions can produce changes in accordance with the desired. Observations made refer to two aspects, namely teacher observation and student observation, (2). Result of Writing Description by applying neighborhood walk strategy.

Analysis of research data was carried out based on the analysis of "flow model" data, proposed by Miles and Huberman (1992) which began with: (1) reviewing all data, (2) data reduction, (3) data presentation, and (4) summarizing results research.

The success of teachers and students in learning with the neighborhood walk strategy using the assessment observation sheet as follows:

1) Evaluation of teacher activities in implementing learning with neighborhood walk strategy with Very Good qualifications (BS) with number 4, good (B) with number 3, enough (C) with number 2, Less (K) with number 1

2) Evaluation of writing descriptions with neighborhood walk strategy using assessment guidelines writing descriptions with indicators using sequence of information about things that are described endlessly, using descriptions that are able to enliven the imagination of the reader as if they saw, heard, felt something that was described, consistent with the topic, stated details of the object which is described in full, the formation of words, the 
preparation of sentences in accordance with the rules of the Indonesian language, the use of spelling and punctuation is maintained.

To measure the success of teachers and students for each action used the following success rates.

Table: 3.1 Table of Teacher and Student Success Rates

\begin{tabular}{cccc}
\hline interval rate & Score & Value & Category \\
\hline $85-100 \%$ & 5 & A & Very good \\
$70-84 \%$ & 4 & B & Good \\
$55-69 \%$ & 3 & C & Enough \\
$50-54 \%$ & 2 & D & Less \\
$0-49 \%$ & 1 & E & Very Less \\
\hline
\end{tabular}

An indicator of the success of this class action research, if the average student learning outcomes in writing a description reach the completeness criteria of at least 75 individually and classically obtain a minimum KKM of $85 \%$.

\section{RESULTS AND DISCUSSION}

In accordance with the results of observations of the teaching activities of teachers for the first cycle of the first meeting of the 9 planned indicators of teacher assessment there are two indicators in the category of assessment (Good), namely the activity motivates students in understanding about the environment and the second indicator of observation directed at environmental details. There are 3 (three) qualified assessment indicators (sufficient), namely indicator 3 determines the topic, theme, and title in accordance with the object / environment observed, indicator 8 description of the object / environment observed with effective sentences, and indicator 9 publishes the essay in front of the class through reading the final draft. Furthermore, there are 4 indicators that qualify (lacking), namely indicator 4 makes the outline in accordance with the scope of observation of environmental objects, indicator 5 constructs topic sentences and explanatory sentences are descriptions of observed objects / environments, indicator 6 shows a complete picture of the observed environmental objects, and indicator 7 illustrates a complete and complete description of the overall object details observed. From various aspects of the existing assessment, still found a variety of shortcomings from each teacher's teaching activities that cause the learning process still seems to be not optimal.

Observation results of teacher activities at the second meeting of cycle I which was held on Friday, September 12, 2014 that of the 9 planned teacher assessment indicators, there were 3 (three) of them included in the qualification "Good (B)" is indicator 1 motivated students in understanding about the environment, indicator 2, observations directed at environmental details, and indicator 9 publish essays in front of the class through the reading of the final draft. And 6 qualified indicators (enough), namely indicator 3, determine the topic, theme, and title in accordance with the object / environment observed, indicator 4 makes the outline in accordance with the scope of observation of environmental objects, indicator 5 arranges the topic sentence and explanatory sentence is a description of object / environment observed, and indicator 6 shows a complete picture of the observed object environment, indicator 7 illustrates a complete and complete description of the entire object details observed, indicator 8 description of the object / environment observed in an effective sentence, so that of all 
indicators Teacher teaching assessment at the second meeting of the first cycle reached a score of 30 with a percentage of $83.33 \%$ with the qualification "Good (B)". So it can be concluded that from $2 \mathrm{x}$ meetings in cycle I the percentage accumulated 76.38 with the qualification "Good (B)".

1) Observation of Student Activity Cycle I

Based on student learning activities found during the learning process activities for the first cycle of the first meeting which took place on Thursday, September 11, 2014. Based on these observations, students' motivation on understanding the environment is in the "Good (B)" qualification of 3 (three) all descriptors are implemented namely 1, 2, and 9. Two qualified indicators (Fair), namely indicators 7 and 8. While 4 (four) indicators are in qualification (Less), namely indicators 3, 4, 5, and 6. Based on Accumulation of score achievement is reaching score 29 is in the "Good" qualification.

In the first cycle of the second meeting which took place on Friday, September 12, 2014. In the results of these observations, 3 descriptors were in qualification (Good), namely indicators 1, 2, and 9. And 5 indicators were in qualification (Fair), namely 3, 4, 5, 6, and 7 , while 1 (one) indicator is in qualification (Less), that is indicator 8 .

Based on the accumulation of achievements from two meetings in the second cycle a score of 29 in qualifications (Good). So the conclusion of $2 \mathrm{x}$ meetings in cycle 1 is accumulation that is entered in the qualification "Good (B)".

2) Results of Writing Essays Description Cycle I

Of the 38 students after writing a description essay, there are 3 students with "very low" qualifications, 11 students who are included in "poor" qualifications, 12 "adequate" qualification students, 10 "good" qualification students, and 2 "very good" qualification students. the KKM standards required are 75 individually and $85 \%$ completeness classically have not reached the target in accordance with the indicators of success that have been set, so it still needs to be followed up at the next learning phase, namely the second cycle.

Observation results of teacher activities at the second meeting of cycle I which was held on Friday, September 19, 2014 that of the 9 planned teacher assessment indicators, there were 7 (seven) indicators of qualifying as "Good (B)" namely indicators 1, 2, 3, 4, 6, 8, and 9. while 2 (two) other indicators are still in the category of "Enough (C)", namely indicators 5 and 7 compose topic sentences and explanatory sentences are descriptions of the object / environment being observed and indicator 7 namely, describe a complete and complete description of the overall object details observed, so that from the overall indicators of teacher teaching assessment at the second meeting of cycle II with the qualification "Good (B)". so it can be concluded that from 2x meetings in cycle II with the qualification "Good (B)"

3) Observation of Student Activity Cycle II

Based on student learning activities that were found during the learning process activities for the second cycle of the first meeting which took place on Thursday, September 18, 2014. On the results of these observations, there were 5 qualification entry indicators (Good), namely indicators 1, 2, 3, 4, and 9. And 4 (four) indicators are in the qualification (Fair) that is, indicators 5, 6, 7, and 8. Based on the accumulation of achievements namely the observation of student learning activities in writing a description essay with a Neighborhood Walk strategy with qualifications (Good).

In the second cycle of the second meeting which took place on Friday, September 19, 2014. In the results of these observations, there were 7 indicators that were in the qualifications (Good), namely indicators 1, 2, 3, 4, 5, 6, and 9. And there are 2 (two) 
indicators are in the qualification (Fair), namely 8 and 7. Based on the accumulation of achievement of observations of student learning activities in the second cycle of the second meeting entered in the qualification (Good). So the conclusions of the $2 \mathrm{x}$ meetings in the second cycle of the accumulation of observations of student learning activities in writing a description essay with the Neighborhood Walk strategy are in the qualification "Good (B)"

4) Results of Writing Essay Description Cycle II

Of the 38 students after writing a description essay there are 1 students with "very low" qualifications, 5 students who are included in "poor" qualifications, 8 students of "sufficient" qualifications, 18 students of "good" qualifications, and 6 students of "very good" qualifications.

In accordance with the required KKM standards that is 75 individually and $85 \%$ completeness has reached the target in accordance with the indicators of success that have been set, so it does not need to be followed up at the next learning phase, namely cycle III

\section{CONCLUSION}

The results showed that the application of the Neighborhood Walk strategy to improve the ability to write descriptive essays in fifth grade students of SDN BTIP IKIP II in cycle I was not optimally implemented, which was marked by a lack of implementation. (1) The application of the Neighborhood Walk strategy to teacher teaching activities and student learning activities in teaching Indonesian grade V elementary school in cycle I of the two meetings is in qualification (Good) and there is an improvement in every indicator in cycle II is in qualification (Good). While student learning activities are in the qualifications (Good) and there is also an improvement of each indicator in the second cycle, (2) The application of the Neighborhood walk strategy to improve learning outcomes writing description of the fifth grade elementary school students in the first cycle is in the qualification (Enough) and occurs increasing the results of writing a description in the second cycle which is in the category (Good).

Teachers are advised to use the Neighborhood Walk strategy as an alternative strategy in learning to write descriptions while still paying attention to the linguistic element, because the application of the Neighborhood walk strategy provides opportunities for students with high intelligence to be able to describe an object well after holding observations of the object directly.

\section{ACKNOWLEDGEMENTS}

\section{REFERENCE}

Depdikbud. 1994/1995, Kurikulum Pendidikan Dasar. Garis-garis Besar Proram Pengajaran Sekolah dasar. Jakarta: Depdikbud

Elliss, A., standal, T., Pennau, J., Rummel, M.K. 1989. Elementary Language arts Instruction, New Jessy: Praktice Hall.

Kemmis, S. dan R.Mc. Taggart. 1992. The Action Research Planner. Victoria: Deakin Universit 
Kustino. 1996. Intensitas Pemanfaatan Sumber Belajar Lingkungan Masyarakat Oleh Guru Sekolah dasar di Kabupaten Pemalang. Jawa Tengah. Jurnal Pendidikan Humaniora dan Sains. Tahun 2, Nomor $1 \& 2$ September $95 \& 96$.

Puskur Depdiknas. 2003. Kurikulum 2004. Jakarta: Depdikbud

Ramli, A. 1999. The Expanding Emvironment Aproach in Elementary social studies Education. Dalam Jurnal Ilmu Pendidikan. Tahun 29 Nomor 1 Januari 1999

Suparno, 2000. Budaya Komunikasi yang terungkap dalam Wacana Bahasa Indoensia. Pidato Suparno, 2001.Pengukuhan Guru Besar pad Fakultas Sastra Universitas Negeri Malang pada Tanggal Suparno, 2001.20 November 2000.

Suparno, 2001. Pembelajaran bahasa Indonesia dengan Pendekatan Kontekstual. Makalah disajikan dalam simposiun Guru di Wisma Jaya Raya Bogor, 2-6 November 2001.

Suparno dan Muhammad Yunur. 2002. Keterampilan dasar Menulis. Buku Materi Pokok PGSD Modul 1-6 Jakarta. Pusat penerbitan Universitas terbuka.

Syafi'ie, iman. 1988. Retorika dalam Menulis. Jakarta: Depdikbud

Tompkins, G.., 1994. Teaching Writing process and Product. New York: McMillon College Publisher. 